Arq. Bras. Med. Vet. Zootec., v.61, n.4, p.996-999, 2009

\title{
Communication
}

[Comunicação]

\section{Isolation of rotavirus from asymptomatic dogs in Brazil}

\author{
[Isolamento de rotavírus de cães assintomáticos no Brasil] \\ V.L.A. Ruiz ${ }^{1}$, P.E. Brandão ${ }^{2}$, F. Gregori ${ }^{1}$, C.A.R. Rodriguez ${ }^{2}$, S.L.P. Souza ${ }^{2}$, J.A. Jerez ${ }^{2}$ \\ ${ }^{1}$ Centro de Pesquisa e Desenvolvimento de Sanidade Animal - Instituto Biológico \\ Av. Conselheiro Rodrigues Alves, 1252 \\ 04014-002 - São Paulo, SP \\ ${ }^{2}$ Faculdade de Medicina Veterinária e Zootecnia - USP - São Paulo, SP
}

\begin{abstract}
Rotaviruses (Reoviridae: Rotavirus), the causative agents of acute diarrhea in mammals, including man and birds, possess a nonenveloped triple-layered icosahedral capsid about $75 \mathrm{~nm}$ diameter, with a characteristic 11segmented genome of double-stranded RNA (dsRNA) (Estes and Cohen, 1989). The genus Rotavirus is subdivided both serologically, based on the inner capsid VP6 protein, and electropherotypically, based on the arrangement of the 11 dsRNA segments, into seven groups (A to $\mathrm{G})$. Groups $\mathrm{A}, \mathrm{B}$, and $\mathrm{C}$ are found in both humans and animals, whereas groups D, E, F, and $G$ have been found only in animals to date. In most cases, the electrophoretic pattern of the genome of group A rotaviruses is composed of four high-molecular-weight dsRNA segments (numbered 1 to 4), two middle-sized segments (5 and 6), a distinctive triplet of segments (7 to 9), and two smaller segments (10 and 11) (Estes and Kapikian, 2007).
\end{abstract}

Canine rotavirus most often causes mild enteritis, especially in pups younger than two weeks, but the virus is also found in health animals (Schwers et al., 1983; Mochizuki et al., 1986).

To date, only 10 isolates of canine rotavirus have been reported, including three isolates from the USA, two from France, two from Japan, two from Italy, and one from Korea (England and Poston, 1980; Fulton et al., 1981; Hoshino et al., 1982; Hoyois et al., 1982; Mochizuki and Hsüan,

Recebido em 16 de dezembro de 2008

Aceito em 27 de abril de 2009

E-mail: letticie@biologico.sp.gov.br
1984; Martella et al., 2001; Mochizuki et al., 2001; Kang et al., 2007).

In Brazil, the detection of rotavirus on fecal samples of dogs has already been reported (Gabbay et al., 2003; Catroxo et al., 2005), but no isolations have been described so far. This study reports the isolation in cell culture and characterization in polyacrylamide gel electrophoresis of rotavirus from fecal specimens of asymptomatic dogs in Brazil.

Fecal specimens were collected from nine asymptomatic adult stray dogs kept at a Zoonosis Control Center located in Osasco municipality, SP. These animals have been removed from streets as part of an animal welfare/rabies control program. Fecal suspensions were prepared as $20 \%(\mathrm{v} / \mathrm{v})$ in $0.1 \mathrm{M}$ Tris/ $1.5 \mathrm{mM} \mathrm{CaCl}_{2}, \mathrm{pH} 7.3$, and centrifuged at $12,000 \mathrm{~g}$ for 30 minutes at $4^{\circ} \mathrm{C}$. Total RNA was extracted from the supernatants with phenol/chloroform and resolved with polyacrylamide gel electrophoresis (PAGE) in $3.5 \%-7.5 \%$ polyacrylamide gel with $20 \mathrm{~mA}$ for two hours, and stained with silver as described by Herring et al. (1982). The NCDV strain of group $\mathrm{A}$ and Tris buffer were included as positive and negative controls, respectively.

For rotavirus isolation, PAGE-positive fecal samples were diluted 1:5 (v/v) in phosphate buffered saline (PBS) and centrifuged at 3,000g for 30 minutes at $4^{\circ} \mathrm{C}$. The supernatant was filtered using $0.22 \mu \mathrm{m}$ membranes ${ }^{1}$ and then diluted 1:2 in viral activation solution $(0.14 \mathrm{M}$ $\mathrm{NaCl}, 5.37 \mathrm{mM} \mathrm{KCl}, 0.4 \mathrm{mM} \mathrm{Na} \mathrm{HPO}_{4}, 0.44 \mathrm{mM}$

${ }^{1}$ Millex Filters 0,22 $\mu \mathrm{m}$, Millipore ${ }^{\circledR}$ - São Paulo, Brazil. 
$\mathrm{KH}_{2} \mathrm{PO}_{4}, 5.55 \mathrm{mM}$ glucose, and $10 \%$ trypsin). One milliliter of the activated inoculum was added to MA-104 cells monolayers grown for 48 hours in $25 \mathrm{~cm}^{2}$ flasks in Medium $199^{2}$ supplemented with $5 \%$ bovine fetal serum (BFS). After one hour of adsorption at $37^{\circ} \mathrm{C}$, the inoculum was discarded and the cells were supplied with $7 \mathrm{~mL}$ of Medium 199 with $10 \mu \mathrm{g} / \mathrm{mL}$ trypsin and incubated at $37^{\circ} \mathrm{C}$.

Cells were daily observed under light microscope for cytopathic effects. Six serial passages were carried out with $1 \mathrm{~mL}$ of the previous passage and each one was monitored by PAGE with the protocol described above.

Two of the nine fecal samples resulted in a weak signal in PAGE, characterized by faint bands

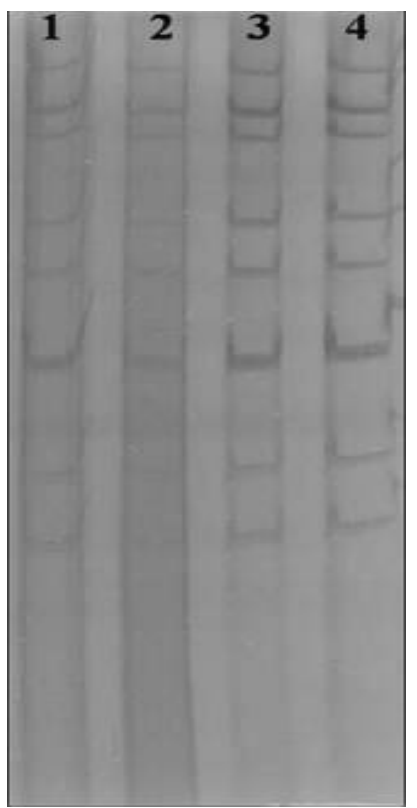

prior virus isolation and were thus elected for rotavirus isolation. Cell culture inoculation of these two samples resulted in a rotavirus-like cytopathic effect from the second passage on, characterized by cell rounding and net-like appearance of the monolayers 48 hours postinoculation. It was possible to detect an electrophoretic pattern typical of group A rotaviruses in both samples after the first (strain $\mathrm{Br}-01$ ) and second (strain Br-02) passages with similar genomic segments mobilities (Fig. 1). Group A rotavirus has been detected and isolated from two adult stray dogs showing no signs of enteritis at the time of sample collection during a survey in animals kept in a Brazilian Public Health animal facility.
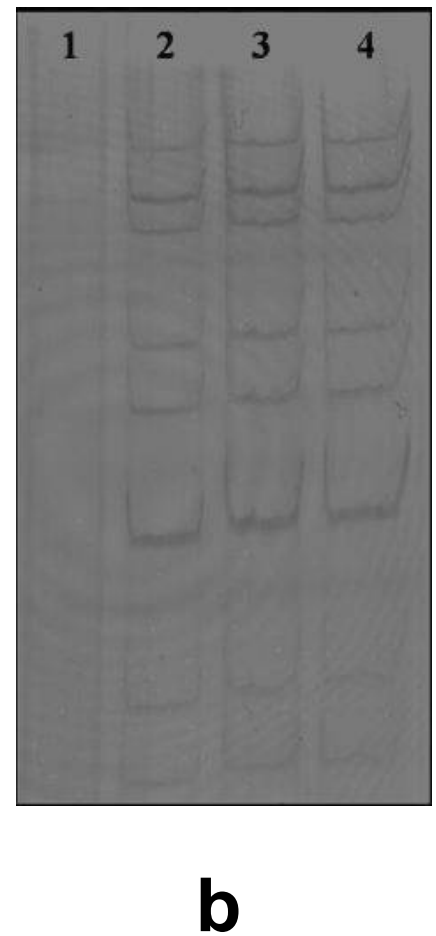

Figure 1. Polyacrylamide gel electrophoresis of canine rotavirus dsRNA genome stained with silver. a: strain $\mathrm{Br}-01: 1^{\text {st }}, 2^{\text {nd }}, 3^{\text {rd }}$ and $4^{\text {th }}$ passages; b: strain Br-02: $1^{\text {st }}, 2^{\text {nd }}, 3^{\text {rd }}$ and $4^{\text {th }}$ passages.

Fecal samples of dogs showing clinical signs of gastroenteritis were positive by ELISA and direct electron microscopy for the presence of rotavirus in Brazil (Gabbay et al., 2003; Catroxo et al., $2005)$, but there are no reports on virus isolation in cell cultures hitherto.

${ }^{2}$ Gibco $^{\circledR}$, Invitrogen ${ }^{\circledR}$ - Massachusetts, USA.
Electrophoresis of dsRNA of strains $\mathrm{Br}-01$ and Br-02 resulted the characteristic 4-2-3-2 group A rotavirus electropherotype, compatible with dog rotavirus described elsewhere (Estes and Kapikian, 2007).

Canine rotavirus isolation in MA-104 cells could be achieved from fecal samples collected from symptomatic puppies as already described in 
countries such as USA (England and Poston, 1980; Fulton et al., 1981), Japan (Mochizuki and Hsüan, 1984; Mochizuki et al., 2001), Italy (Martella et al., 2001), and North Korea (Kang et al., 2007). Regarding the isolation from fecal samples taken from asymptomatic dogs, reports are scarce (Hoyois et al., 1982; Hoshino et al., 1982), what allow one to speculate that not only asymptomatic carriers is one possible condition of dogs regarding rotavirus infection but also that these animals might shed low titers of rotavirus in their feces.

Strains $\mathrm{Br}-01$ and $\mathrm{Br}-02$ showed cytopathic effect after the $2^{\text {nd }}$ passage in MA-104 cells, similarly to the above mentioned canine rotavirus isolation reports, and a clearer rotavirus electropherotype in PAGE after virus isolation when compared to the original fecal samples, showing that cell culture isolation can increase PAGE sensitivity and allow a more accurate detection of this virus in asymptomatic animals.
Seroepidemiological surveys have shown that a high frequency of anti-rotavirus antibodies can be expected in adult dogs (Mochizuki et al., 1986), meaning that these animals are either continuously exposed to this pathogen or harbor it as asymptomatic carriers.

Transmission of rotavirus amongst humans and dogs has already been experimentally (Tzipori and Makin, 1978) and naturally (Nagakomi et al., 1992) proved and canine rotaviruses could be isolated even from asymptomatic humans (Nagakomi and Nagakomi, 2000). Thus, dogs carrying rotavirus and freely wandering in streets may pose a risk to rotavirus transmission to humans, mainly to the young, and might be a neglected link in viral gastroenteritis epidemiological chain.

Keywords: rotavirus, isolation, PAGE, asymptomatic dogs

\section{RESUMO}

Relata-se o isolamento de rotavírus, a partir de material fecal de dois cães assintomáticos, no Brasil. A ocorrência de rotavírus foi pesquisada em amostras fecais de nove cães assintomáticos, provenientes do Centro de Controle de Zoonoses do municipio de Osasco, SP. Duas das nove amostras analisadas, por eletroforese em gel de poliacrilamida, foram positivas. O isolamento de rotavírus foi realizado em linhagem de células MA-104, com adição de $10,0 \mu \mathrm{g} / \mathrm{mL}$ de tripsina ao meio de manutenção, e confirmado pelo eletroferótipo característico de grupo A.

Palavras-chave: rotavírus, isolamento, PAGE, cães assintomáticos

\section{REFERENCES}

CATROXO, M.H.B.; PONGILUPPI, T.; GREGORI, F. et al. Detecção de rotavírus pelas técnicas de microscopia eletrônica de transmissão em fezes de cão com diarréia. Arq. Inst. Biol. São Paulo, v.72, supl.2, p.23, 2005. (Resumo).

ENGLAND, J.J.; POSTON, R.P. Electron microscopic identification and subsequent isolation of a rotavirus from a dog with fatal neonatal diarrhea. Am. J. Vet. Res., v.41, p.782783, 1980.

ESTES, M.K.; COHEN, J. Rotavirus gene structure and function. Microbiol. Rev., v.53, p.410-449, 1989.

ESTES, M.K.; KAPIKIAN, A.Z. Rotaviruses. In: KNIPE, D.M.; HOWLEY, P.M. (Eds). Fields virology. Philadelphia: Lippincott Williams \& Wilkins, 2007. p.1917-1927.

FULTON, R.W.; JOHNSON, C.A.; PEARSON, N.J. et al. Isolation of a rotavirus from a newborn dog with diarrhea. Am. J. Vet. Res., v.42, p.841843, 1981.

GABBAY, Y.B.; HOMEM, V.S.F.; MUNFORD, $\mathrm{V}$. et al. Detection of Rotavirus in dogs with diarrhea in Brazil. Braz. J. Microbiol., v.34, p.77-80, 2003.

HERRING, A.L.; INGLIS, N.F.; OJEH, C.K. et al. Rapid diagnosis of rotavirus infection by direct detection of viral nucleic acid in silverstained polyacrylamide gels. J. Clin. Microbiol., v.16, p.473-477, 1982.

HOSHINO, Y.; WYATT, R.G.; SCOTT, F.W. et al. Isolation and characterization of a canine rotavirus. Arch. Virol., v.72, p.113-125, 1982. 
HOYOIS, P.; SCHWERS, A.; PASTORET, P.P. Isolation of rotavirus from stools of farm dogs in close contact with cattle. Ann. Med. Vet., v.126, p.335-338, 1982.

KANG, B.K.; SONG, D.S.; JUNG, K.I. et al. Genetic characterization of canine rotavirus isolated from a puppy in Korea and experimental reproduction of disease. J. Vet. Diagn. Invest., v.19, p.78-83, 2007.

MARTELLA, V.; PRATELLI, A.; ELIA, G. et al. Isolation and genetic characterization of two G3P5A[3] canine rotavirus strains in Italy. $J$. Virol. Methods, v.96, p.43-49, 2001.

MOCHIZUKI, M.; HSÜAN, S. Isolation of a rotavirus from canine diarrheal feces. Jpn. J. Vet. Sci., v.46, p.905-908, 1984.

MOCHIZUKI, M.; HASHIMOTO, M.; ISHIDA, $\mathrm{T}$. Recent epidemiological status of canine viral enteric infections and Giardia infection in Japan. Jpn. J. Vet. Sci., v.63, p.573-575, 2001.
MOCHIZUKI, M.; MINAMI, K.; SAKAMOTO, H. Seroepizootiologic studies on rotavirus infections of dogs and cats. Jpn. J. Vet. Sci., v.48, p.957-964, 1986.

NAKAGOMI, T.; MOCHIZUKI, M.; ABOUDY, Y. et al. Hemagglutination by a human rotavirus isolate as evidence for transmission of animal rotaviruses to humans. $J$. Clin. Microbiol., v.30, p.1011-1013, 1992.

NAKAGOMI, T.; NAKAGOMI, O. Human rotavirus HCR3 possesses a genomic RNA constellation indistinguishable from that of feline and canine rotaviruses. Arch. Virol., v.145, p.2403-2409, 2000 .

SCHWERS, A.; DAGENAIS, L.; CHAPPUIS, G. et al. Propagation of bovine rotavirus by young dogs. J. Comp. Pathol., v.93, p.135-141, 1983.

TZIPORI, S.; MAKIN, T. Propagation of human rotavirus in young dogs. Vet. Microbiol., v.3, p.55-63, 1978. 